\title{
65. WATER CONTENT AND ATTERBERG LIMITS OF SEDIMENTS AT DEEP SEA DRILLING PROJECT HOLES 417A AND 418A, LEGS 51 AND 52, WEST ATLANTIC OCEAN
}

\author{
Adrian F. Richards and Edwin Fager, Marine Geotechnical Laboratory, Lehigh University, Bethlehem, Pennsylvania
}

\begin{abstract}
Fourteen water contents and eight Atterberg limits from Hole 417 A and two water contents from Hole $418 \mathrm{~A}$ are reported. The Hole 417A sediments are middle Eocene pelagic clay and radiolarian clay and ooze, which are classified as type $\mathrm{CH}$ inorganic clays of high plasticity. Water contents range from 49 to 70 per cent dry weight, liquid limits from 115 to 149 per cent, plastic limits from 34 to 42 per cent, and liquidity indexes from 6 to 39 . Values are similar to previous DSDP Atterberg limit data reported in the literature.
\end{abstract}

\section{INTRODUCTION}

The Atterberg limits define the water content, expressed as a percentage of the dry weight, between arbitrary states of sediment consistency. The liquid limit defines the water content occurring at the arbitrary boundary between the liquid and plastic states, while the plastic limit defines a comparable arbitrary boundary between the plastic and semisolid states. The classification of sediments for engineering purposes is based upon grain-size characteristics and the Atterberg limits.

This paper reports on the following: (1) the determination of 14 water contents and 8 Atterberg limits from Hole 417A, Leg 51, and 2 water contents from Hole 418A, Leg 52 ; (2) the engineering classification for the 8 samples from Hole 417A; and (3) compares these 8 samples with other DSDP Atterberg limit data. The location of the two sites is shown in Figure 1; water depths are 5468 meters at Site 417 and 5511 meters at Site 418.

\section{ANALYTICAL METHODS}

\section{Water Content}

This test follows the procedure specified in ASTM (1977) Standard D2216-71, except that covered containers were not used because samples were weighed immediately after removal from the oven and the absorption of atmospheric moisture was not considered to be of consequence. The oven used was a thermostatically controlled forced-draft type, and samples were oven-dried at $110^{\circ} \mathrm{C}$ overnight. All data are reported in per cent dry weight, and no corrections have been made for salt content.

\section{Liquid Limit}

This test was made using hand-operated machines and follows the procedure specified in ASTM (1977) Standard D423-66, except for the following modifications. Samples were not dried before testing and when additional water was needed, artificial sea water having a salinity of $32 \%$ was used. (Although a salinity of $32 \%$ was lower than the $35 \%$ presumed for these sediments, it was readily available.)
Sieving was considered unnecessary because the sediments are very fine grained.

Difficulties were encountered because large ( 2 to $3 \mathrm{~mm}$ ) air bubbles formed when some of the samples were worked. The presence of bubbles when the single deep groove was cut and during the test (when the groove was closing) caused many tests to be rerun; what should have been short tests often extended over a considerable length of time.

\section{Plastic Limit}

This test follows the procedure specified in ASTM (1977) Standard 424-59, except as follows. Subsamples were taken from the same homogenized sample as for the liquid limit test and dried in an oven or by using an infrared lamp. The moisture content was adjusted using artificial sea water having a salinity of $32 \%$. A plexiglass sheet was used instead of a ground-glass plate. Multiple attempts to attain the prescribed $3.2-\mathrm{mm}$ diameter thread usually were necessary because of the difficulty in reaching the end point.

\section{RESULTS AND DISCUSSION}

Water content data for samples from Holes $417 \mathrm{~A}$ and $418 \mathrm{~A}$ are presented in Table 1. Atterberg limit measurements on Hole 417A samples are given in Table 2. In Table 2 , the plasticity index, $I_{p}$, is defined by Equation 1 as follows:

$$
{ }_{P}=w_{L}-w_{P}
$$

and the liquidity index, IL, expressed as a percentage, is defined by Equation 2 as follows:

$$
\mathrm{I}_{\mathrm{L}}=\frac{\mathrm{w}-\mathrm{w}_{\mathrm{P}}}{\mathrm{I}_{\mathrm{P}}}
$$

in which $w$ is the initial water content, $w_{\mathrm{L}}$ is the liquid limit, and $\mathrm{w}_{\mathrm{p}}$ is the plastic limit.

A plasticity chart (Figure 2) graphically shows that the sediment samples listed in Table 2 fall above the $\mathrm{A}$ line that separates typically inorganic sediments above from typ- 


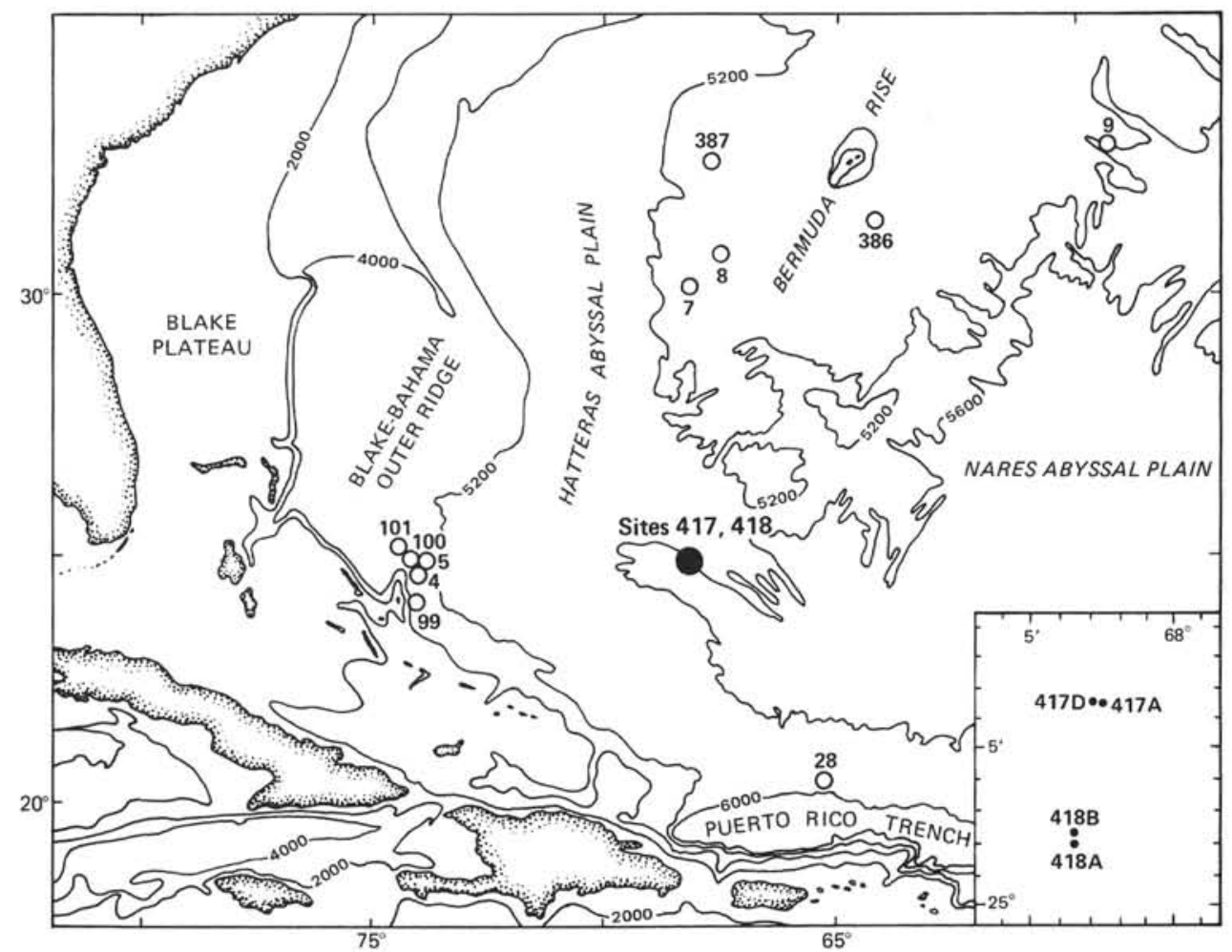

Figure 1. Location map of Sites 417 and 418.

TABLE 1

Water Content Data

\begin{tabular}{cccccc}
\hline Leg & Hole & $\begin{array}{c}\text { Sample } \\
\text { (Interval in cm) }\end{array}$ & $\begin{array}{c}\text { Sub-Bottom } \\
\text { Depth }(\mathrm{m})\end{array}$ & $\begin{array}{c}\text { Water Content } \\
\text { (\% dry wt.) }\end{array}$ & $\begin{array}{c}\text { Date of } \\
\text { Recovery }\end{array}$ \\
\hline 51 & $417 \mathrm{~A}$ & $1-3,8-10$ & $0-8.5$ & 77 & $12-3-76$ \\
51 & $417 \mathrm{~A}$ & $2-2,33-37$ & $8.5-18.0$ & 66 & $12-4-76$ \\
51 & $417 \mathrm{~A}$ & $3-4,29-36$ & $18.0-27.5$ & 66 & $12-4-76$ \\
51 & $417 \mathrm{~A}$ & $6-4,130-134$ & $46.5-56.0$ & 70 & $12-4-76$ \\
51 & $417 \mathrm{~A}$ & $8-4,101-103$ & $65.5-75.0$ & 61 & $12-4-76$ \\
51 & $417 \mathrm{~A}$ & $9-4,64-69$ & $75.0-84.5$ & 62 & $12-4-76$ \\
51 & $417 \mathrm{~A}$ & $10-3,106-108$ & $84.5-94.0$ & 49 & $12-4-76$ \\
51 & $417 \mathrm{~A}$ & $11-2,72-77$ & $94.0-103.5$ & 53 & $12-4-76$ \\
51 & $417 \mathrm{~A}$ & $12-2,121-125$ & $103.5-113.0$ & 56 & $12-4-76$ \\
51 & $417 \mathrm{~A}$ & $12-4,55-64$ & $103.5-113.0$ & 58 & $12-4-76$ \\
51 & $417 \mathrm{~A}$ & $14-1,95-99$ & $122.5-132.0$ & 53 & $12-4-76$ \\
51 & $417 \mathrm{~A}$ & $15-2,106-111$ & $132.0-141.5$ & 69 & $12-4-76$ \\
51 & $417 \mathrm{~A}$ & $16-4,61-66$ & $141.5-151.0$ & 59 & $12-4-76$ \\
51 & $417 \mathrm{~A}$ & $19-1,111-115$ & $170.0-179.5$ & 39 & $12-5-76$ \\
52 & $418 \mathrm{~A}$ & $6-1,62-66$ & 158.8 & 48 & $2-14-77$ \\
52 & $418 \mathrm{~A}$ & $7-5,58-63$ & 174.6 & 63 & $2-14-77$ \\
\hline
\end{tabular}

${ }^{\mathrm{a} N o t}$ corrected for salt content.

ically organic sediments below. Figure 2, adapted from Deep Sea Drilling Project Technical Report 9 (1976) by Davie et al. (1978), also shows numerous other data. The clay from Site 302, which has similar properties to the data presented in this paper, is from the Sea of Japan (Leg 31).

All of the samples listed in Table 2 are middle Eocene pelagic clays and radiolarian clays and oozes. Their engineering classification is $\mathrm{CH}$, or inorganic clays of high plasticity, according to ASTM (1977) Standard D2487-69. It may be inferred from the high liquid limits that these sediments are characterized by high compression indexes.

At all burial depths, the liquid limit is appreciably higher than the water content, which is reflected in the unusually low liquidity indexes. If the sediment at Site 417 is normally consolidated, which would be expected from the presumed slow rate of deposition, then the following relationships are postulated from the rationale presented by Skempton (1970). Nearly identical liquidity indexes over burial depths of about 13 to 50 meters suggest that consolidation is minimal to a depth of somewhat greater than 50 meters. The rapid decrease of liquidity index between about 50 and 90 meters suggests significant consolidation over this depth interval. The increasing liquidity indexes below about 90 meters implies that consolidation is not occurring, possibly due to cementation or some other cause.

\section{ACKNOWLEDGMENTS}

We thank the shipboard party for collecting the samples. Doreen Volk made the water content tests.

\section{REFERENCES}

ASTM, 1977. 1977 Annual book of ASTM standards: part 19: Philadelphia (American Soc. for Testing and Materials).

Davie, J.R., Fenske, C.W., and Serocki, S.T., 1978. Geotechnical properties of deep continental margin soils, Marine Geotechnology, v. 3, no. 1, p. 85-119.

Deep Sea Drilling Project, 1976. Soils study continental margin sites, bearing capacity study of seafloor soils, Middle Atlantic Ridge, Atlantic Ocean, Deep Sea Drilling Project Tech. Rept. 9.

Skempton, A.W., 1970. The consolidation of clays by gravitational compaction, Quart. Jour. Geol. Soc. London, v. 125, p. 373-412. 
TABLE 2

Engineering Index Properties for Leg 51, Hole 417A

\begin{tabular}{|c|c|c|c|c|c|c|c|c|c|}
\hline $\begin{array}{c}\text { Sample } \\
\text { (Interval in } \mathrm{cm} \text { ) }\end{array}$ & $\begin{array}{l}\text { Range and } \\
\text { Sub-Bottom } \\
\text { Depth (m) }\end{array}$ & Lithology & $\begin{array}{l}\text { Eng. } \\
\text { Class. }\end{array}$ & $\begin{array}{c}\text { Water } \\
\text { Content, } \\
\text { (\% dry wt.) }\end{array}$ & $\begin{array}{c}\text { Liquid } \\
\text { Limit } \\
(\%)\end{array}$ & $\begin{array}{l}\text { Plastic } \\
\text { Limit } \\
(\%)\end{array}$ & $\begin{array}{l}\text { Liquidity } \\
\text { Index } \\
(\%)\end{array}$ & $\begin{array}{l}\text { Plasticity } \\
\text { Index }\end{array}$ & $\begin{array}{c}\text { Notes } \\
\text { (see text) }\end{array}$ \\
\hline $2-2,0-30$ & $\begin{array}{l}8.5-18.0 \\
(13)\end{array}$ & Pelagic clay & $\mathrm{CH}$ & 66 & 115 & 34 & 39 & 81 & \\
\hline $3-4,0-30$ & $\begin{array}{c}18.0-27.5 \\
(23)\end{array}$ & Pelagic clay & $\mathrm{CH}$ & 66 & $122^{\mathrm{a}}$ & 34 & $36^{\mathrm{a}}$ & $88^{\mathrm{a}}$ & Bubbles in clay \\
\hline $6-4,100-130$ & $\begin{array}{c}46.5-56.0 \\
(52)\end{array}$ & Pelagic clay & $\mathrm{CH}$ & 70 & 118 & 39 & 39 & 79 & Bubbles in clay \\
\hline $9-4,70-100$ & $\begin{array}{c}75.0-84.5 \\
(81)\end{array}$ & Pelagic clay & $\mathrm{CH}$ & 62 & 128 & 34 & 30 & 94 & Bubbles in clay \\
\hline $10-3,109-139$ & $\begin{array}{c}84.5-94.0 \\
(90)\end{array}$ & Pelagic clay & $\mathrm{CH}$ & 49 & 149 & $42^{\mathrm{a}}$ & $6^{a}$ & $107^{\mathrm{a}}$ & Bubbles in clay \\
\hline $11-2,40-71$ & $\begin{array}{c}44.0-103.5 \\
(100)\end{array}$ & Pelagic clay & $\mathrm{CH}$ & 53 & 140 & 40 & 13 & 100 & Bubbles in clay \\
\hline $14-1,100-130$ & $\begin{array}{c}122.5-132.0 \\
(128)\end{array}$ & $\begin{array}{l}\text { Rad clay } \\
\text { and ooze }\end{array}$ & $\mathrm{CH}$ & 53 & 140 & $39^{\mathrm{a}}$ & $14^{\mathrm{a}}$ & $101^{\mathrm{a}}$ & \multirow[t]{2}{*}{$\begin{array}{l}\text { Bubbles in clay } \\
\text { and ooze }\end{array}$} \\
\hline $15-2,72-105$ & $\begin{array}{c}132.0-141.5 \\
(138)\end{array}$ & $\begin{array}{l}\text { Rad clay } \\
\text { and ooze }\end{array}$ & $\mathrm{CH}$ & 69 & 142 & 41 & 28 & 101 & \\
\hline
\end{tabular}

a Values \pm from 2 to 3 .

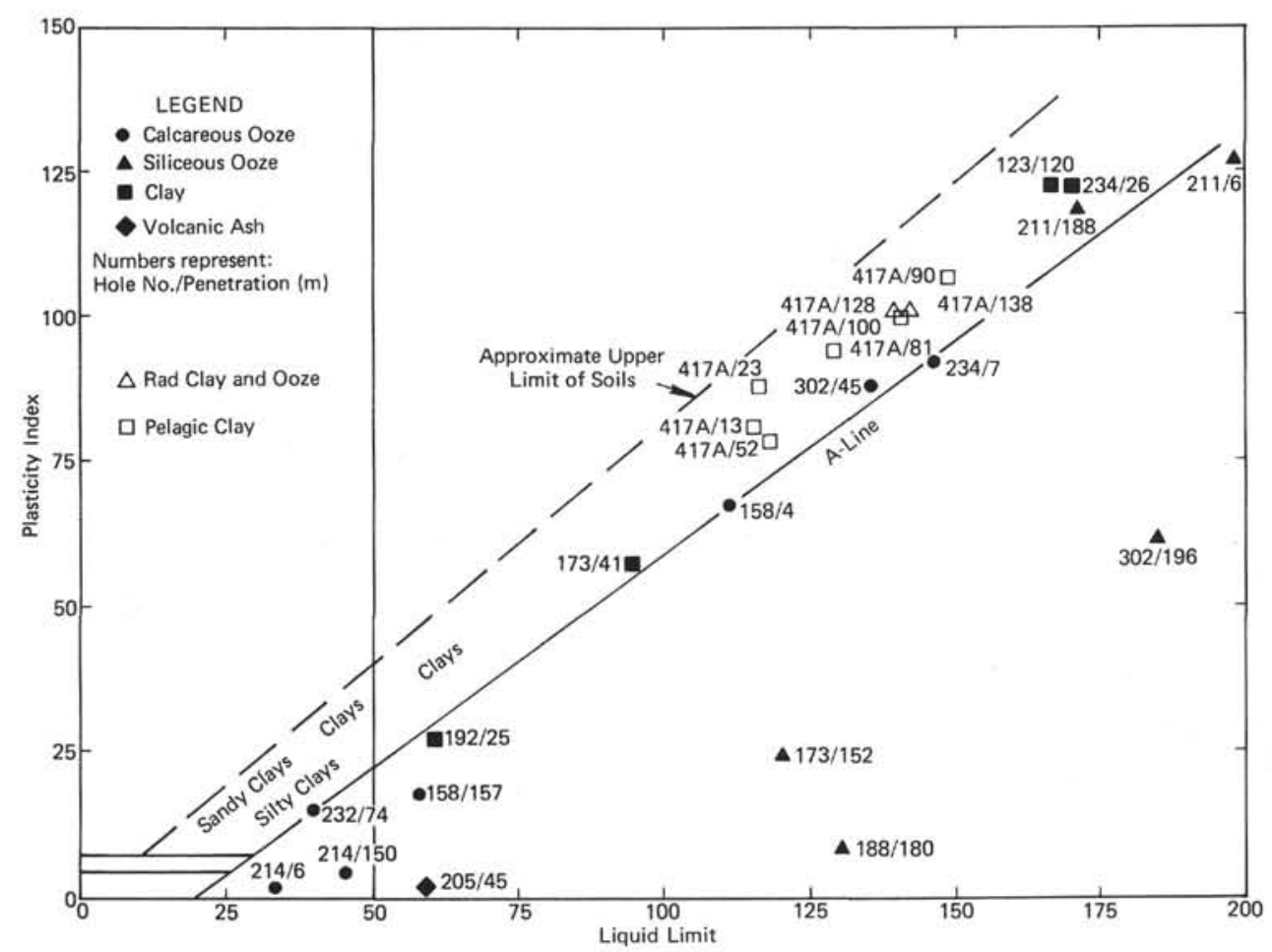

Figure 2. Plasticity chart. Data reported in this paper shown by open triangles and squares; other data and illustration from Davie et al. (1978). 